\title{
Impact of Financial Constraints on the Performance of SMEs - A Study of Sindh Province
}

\author{
Sadia Shaikh ${ }^{1}$ \\ Imam Uddin Khoso ${ }^{2}$
}

\begin{abstract}
SMEs have been efficiently used as the vehicles for promoting innovation, productivity, and the competitiveness of a country's national economy. Across the globe, SMEs have been playing a distinctive role in achieving the socio-economic objectives such as employment generation, poverty reduction, equalizing the distribution of national wealth, fostering innovation, and nurturing institutional competitiveness. The main objective of this study is to empirically examine the extent to which financial constraints hamper the growth of SMEs in Sindh, Pakistan. To collect the primary data, survey questionnaires were distributed to 100 SMEs from different economic sectors and registered in the Chamber of Commerce Offices in Sindh. Seven (7) critical financial constraints to SMEs were determined through the literature and included in the questionnaire. The data were analyzed through descriptive analysis and correlation techniques. The results show that SMEs in Pakistan are severely constrained by financing, particularly external equity. Financial ecosystem for SMEs in Pakistan is not friendly and one-size fits all rules and regulations may not suffice the financing needs of SMEs in Pakistan. It has been observed that the institutional weaknesses and market failures exacerbate the financial constraints of SMEs. The government, exclusively, should develop specialized banks and funds to cater to the financing needs of SMEs in their various stages of the business cycle. Furthermore, the Credit Guarantee Schemes (CGS) should also be launched to share the risk of Financial Institutions for lending to the SMES.
\end{abstract}

JEL Classification: $Q 53, P 33, R 51$

Keywords: Small \& Medium Enterprises, Financial Constraints, Socio-Economic Wellbeing, Business Growth.

\section{INTRODUCTION}

SMEs are critical in delivering sustainable and inclusive globalization. In developed as well as developing countries, SMEs are central to the policies for achieving employment targets, value-added exports, higher income levels, and contributing to enhanced innovation. The existence of vibrant SME-sector has been empirically linked with more inclusive growth and environmental sustainability. According to the SMEDA (2018), in Pakistan, 99 percent of the business units are micro, small \& medium enterprises and their contribution to the GDP of the country is 40 percent. The contribution of SMEs to employment generation is 78 percent which is above average among the South Asian Countries. The globalization has increased the access of firms to world markets, resulting in rapid economic growth. However, the fast-paced growth has resulted in a highly unequal distribution of wealth and the creation of economically imbalanced societies.

SMEs have been widely viewed as the economic apparatuses that spur the growth which results in a more inclusive and equitable distribution of incomes. SMEs' contributions vary widely across the countries, highly dependable upon the business environment they operate in.

\begin{tabular}{llll}
\hline 1- Department of Business Administration, Greenwich University Karachi. Email: sadiakhurram@live.com \\
2- IBA, University of Sindh, Jamshoro. \\
\hline JISR-MSSE & Volume 17 & Number 1 & January-June 2019 \\
\hline
\end{tabular}


All through the period of the post-2008 financial crisis, Pakistan has been continuously facing low economic growth, weak investment ratios, the slow pace of trade, and persistently rising inequality among the masses. Against this backdrop, governments globally rely more on SMEs in policy work in order to ensure that the benefits of growth are broadly and equally shared across the society and to the economic strata at all levels. The 17 goals set out in SDGs by the United Nations can well be achieved through increased and competitive participation of SMEs especially in the promotion of sustainable and inclusive economic growth, provision of employment and decent work, fostering innovation for sustainable industrialization, and by delivering an equitable distribution of income (Boschmans \& Pissareva, 2017). Technological SMEs are essential for delivering environment-friendly production and consumption patterns to ensure sustainability and clean \& green environment. For SMEs to operate efficiently, need a supportive business environment. In comparison to large-sized firms, SMEs should also be given proportionate access to strategic resources such as finance, knowledge networks, skilledlabour force and infrastructure.

There are various barriers which undermine SMEs participation in a nation's economic growth. As a result, a specific stratum of underprivileged people is relatively discontented with their living standards in the backlash against rapid advancement in technology and globalization. According to the sources at State Bank of Pakistan, the disaggregated supply-side data on SME lending is not available, however, demand-side data on borrowing obtained through interviews shows that lending to SMEs by the banks and Financial Institutions is very limited and only meets 12 percent of financing needs of SMEs. It is thus an alarming situation and requires immediate policy interventions to ease the financing issues and help SMEs operate on their full potential. SMEs' lack of access to adequate financing undermines their competitiveness and prevents them from working efficiently. Therefore, the main objective of this paper is to empirically examine the type and intensity of financial constraints and their subsequent impact on firm performance. The study findings of this research would significantly help policymakers in developing relevant strategies to mitigate the financial issues of SMEs operating in Pakistan.

\section{LITERATURE REVIEW}

In a study conducted by Beck \& Demirguc-Kunt (2006), on investigating the constraints hampering firm's growth performance found that the financing obstacles are robustly correlated with the firm's age, size, and type of ownership. Similarly, Leaven \& Woodruff (2007) found that financing constraint has been marked as the most severe growth barrier for SMEs in the developing world. This self-reported perception of financing constraint as a severe growth obstacle has also been practically validated by the authors. Banerjee \& Duflo (2004), surveyed 253 SMEs in India which obtained a loan at government subsidized interest rate. The survey found that the size of the loan was directly proportional to the increase in sales volume of the borrower SMEs which indicates that given access to subsidized interest rate loan, SMEs showed robust growth and suggests that previously those SMEs have been financially constrained. Most importantly the results of world's business environment survey (1999-2000) conducted in 80 countries with a sample size of 10,000 firms showed that the firms which reported access to financing as a severe constraint has experienced a slow output growth (Beck, Demirguc-Kunt, \& Levine, 2005). A considerable amount of the empirical literature on the analysis of financing constraints has concluded that SMEs face financing obstacles because of agency problem and asymmetric information between lenders and the small firms (Blundell, Dearden, \& Meghir, 1996; Bond, Harhoff, \& Van Reenen, 1999).

100 January-June $2019 \quad$ Volume $17 \quad$ Number $1 \quad$ JISR-MSSE




\section{Information Asymmetry and Financial Constraints}

A large number of existing studies in the broader literature have examined the relationship exists between lowered information asymmetry and reduced information opacity with access to bank finance for SMEs. Rahman, Rahman, and Belas (2017) assessed the factors which promote firms' accessibility to capital finance from formal sources in three Central European countries; Slovak Republic, Czech Republic, and Hungary. The data for the study covered micro, small, and medium enterprises and was obtained from the BEEPS survey. The survey was conducted between 2012-2014 from thirty (30) countries to observe the business environment conditions for SMEs in developed, developing, and emerging markets. 793 SMEs data was extracted for the survey from the selected countries. The determinants of access to finance were analyzed separately for each country to have a deeper knowledge of the disparities between the financial structure of each country. Ordinary least square regression was employed to see the correlation between the variables. Similar to the majority of the earlier studies, this study has also taken loan size as a proxy to calculate the accessibility to financing. The study outcomes elucidate that the collateral guarantees have a positive impact on access to bank finance. Moreover, as far as firm characteristics are considered, it was revealed that women-led SMEs receive less finance, innovative firms are more prone to access a larger amount of finance, and smaller sized firms due to no credit history and information asymmetry believed to be riskier thus are ineffectual in receiving bank loans and are credit rationed.

Recent research carried out by Wangmo (2016), on the Bhutanese SME sector to explore the grounds and characteristics of external financing constraints, SMEs face. The authors applied three economic theories; Agency theory, Pecking Order theory, and information asymmetries to develop the theoretical framework. The study enfolded many critical factors related to the firm's capital structure, such as their ability to repay loans, meeting collateral demands and firm-level attributes such as firms age, industry, size, and owners' characteristics. The study investigated the loopholes in SME financing from both the customers' (SME) and the sellers' (banks) perspectives. To analyze the financial constraints faced by both market agents, a sequential mix method exploratory approach was used. For the SME perspective, the quantitative data was collected from the SME owners in Bhutan through field survey and was empirically analyzed through multiple linear regressions. Whereas for the bank's perspective, the qualitative data was gathered from bank credit officers through semi-structured interviews and was evaluated by the means of thematic analyses. The study postulated that the collateral requirements and owners' equity were critical factors to determine external financing capacity of SMEs. The banks with the higher capability to pay back loans have higher subjectivity to access bank finance, and availability of collaterals play a significant role in loans' acquaintance. Moreover, information asymmetries and lopsidedness between banks and SMEs create issues like credit rationing, stringent loaning terms, higher collaterals, favouritism, and prejudices in the lending process.

Furthermore, it has been widely observed that SMEs access to finance is severely constrained by a number of demand and supply-side limitations. Large firms are likely to get financing at economical rates than their counterpart SMEs dealing in similar businesses, owing to asymmetric information and agency problems (Fowowe, 2017). In the demand side constraints, most notably, SMEs have limited financial knowledge towards short- and long-term financial products available in the local and multinational markets, and lack

\begin{tabular}{llll}
\hline JISR-MSSE & Volume 17 & Number 1 & January-June 2019 \\
101
\end{tabular}


willingness to fund investment projects with external financing. In supply-side constraints, financial institutes do not have specific and tailor-made suitable financial tools for SMEs, encompass cumbersome regulatory requirements, demand high collateral, offer high borrowing costs, have lack of equity investments, and impose heavy regulatory compliance costs. SMEs in developing countries thus face multiple challenges due to financial bindings such as accessibility to skilled labour, essential resources and poor infrastructure which severely constrains firms' productivity \& innovation capabilities (Artola, \& Genre, 2011).

Correspondingly, SMEs are generally under-collateralized, lack the expertise required to prepare sophisticated and proper financial statements and have a limited credit history. These constraints are more severe to the SMEs operating in low- and mid-income economies. In the aftermath of the global financial crisis of 2008, SMEs have been disproportionately affected in their access to finance as the large-sized firms carry lower credit risk, hence, transpire to be more favourable applicants to the national and multinational financial institutions. In the post-crisis period, the gap of access to financing for SMEs in comparison to large firms has been considerably widened as SMEs are viewed as higher credit risk entities. SMEs in Pakistan heavily rely on the internal source of financing which limits their ability to undertake long-term investments, expand business units, enter into global markets, and pursue technologically innovative methods \& processes.

In this essence, Naqvi (2011), conducted research on SMEs in Bahawalpur, Pakistan to assess the critical reasons for success and failures of SMEs. The study developed a research model from an earlier study of the Asian Development Bank and generalized the result in the context of Bahawalpur SMEs. The study findings underlined the fundamental issues concerning SME's failure as the lack of access to finance, inefficient government policies and infrastructure, and prevalent institutional corruption. Whereas the critical success factors include marketing factors encompassing customer orientation, business experience and knowledge. Therefore, it is apparent that the lack of access to finance is one of the major pretexts which compromises their competitiveness (Bergthaler, Kang, Liu, \& Monaghan, 2015).

\section{Inadequacies in Access to Financial Capital}

The composition of the SME sector in Pakistan is remarkably diverse in terms of ownership type, age, size, business models, and aspirations of entrepreneur or owner. At the start of a venture, managerial capacity is essential for its survival and growth. Later, the innovation capacity is crucial for the expansion of growth. Due to prevalent financial restraints faced by SMEs and the magnitude of this constraint, the cost and risk of private equity finance should be reduced. Further, the cost of taxes should also not be disproportionately higher on SMEs, to reduce their burden of tax levy. The financing needs of SMEs substantially vary as they move along with their business life cycle (Fort, Haltiwanger, Jarmin, \& Miranda, 2013). It is extremely important that SMEs should be provided with adequate funds for their operations at initial stages of business with government guarantees, as the private sector is reluctant to offer finance in the initial stage. At the start-up stage, SMEs have opaque informational capacity (Berger \& Udell, 1998), higher risk of survival (Levine, 2005), high credit risk failure (Mian, 2006), lack of collateral assets (Steijvers, Voordeckers, \& Vanhoof, 2010), lack of proven track record (St-Pierre \& Bahri, 2011), limited history of trading (De la Torre, Soledad Martinez Peria, \& Schmukler, 2008), among others. As a result, SMEs in this phase heavily depend on the internal source of funding such as retained earnings. In the subsequent growth

102 January-June $2019 \quad$ Volume $17 \quad$ Number $1 \quad$ JISR-MSSE


phases, SMEs seem to survive, grow, and become mature, hence, then they carry business track record, achieve information transparency, offer more collateralized assets, and develop better access to financial markets. Pecking Order Theory (POT) has predicted a firm's financialbehaviour and postulates that when there is a need for financing, a firm prefers internal source of financing. In the case of the external finance requirement, a firm prefers debt over equity source (Frank \& Goyal, 2003). These preferences under POT are based on the assumptions that organizational structures and financial practices of SMEs are significantly different from that of large corporations and they have extremely limited alternatives to issue securities for external financing, particularly equity. Thus, in Pakistan, SMEs seem to follow POT in their financial decisions.

Figure 1: Conceptual Framework: Components of Financial Constraint

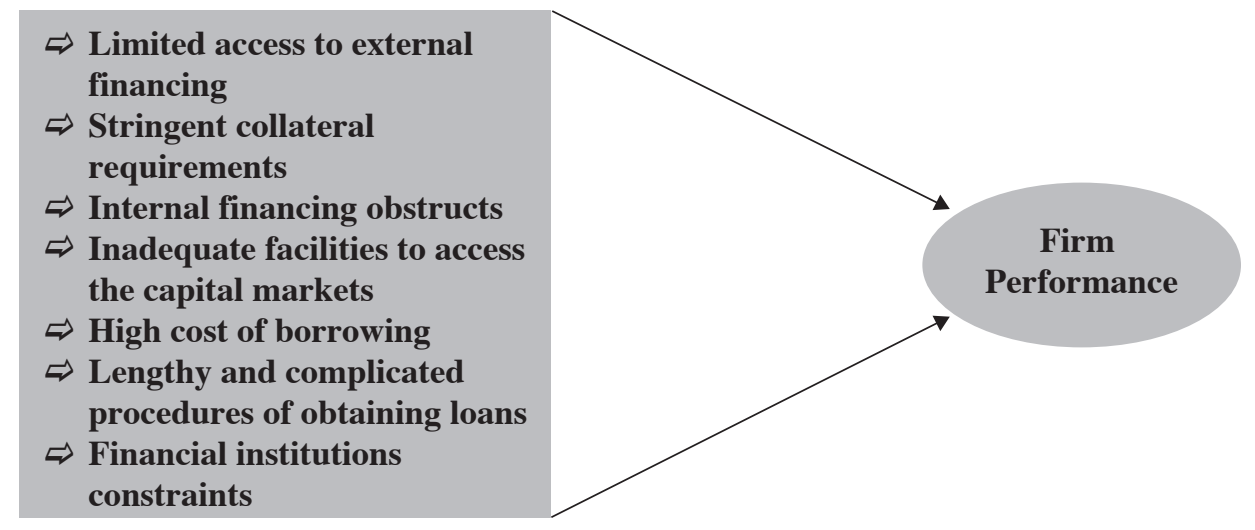

Source: Developed by Authors

\section{RESEARCH METHODOLOGY}

The main objective of this study is to examine the type and intensity of financial constraints that impact the performance of SMEs in Sindh province. A quantitative approach is used in the collection of data and a survey questionnaire was designed to gather the primary data. The seven major constraints related to financial constraint category were determined and were measured on a 5-point Likert scale ranging from the least severe constraint to the most serve constraint. The collected data were analyzed through descriptive statistics and correlation technique. In the sampling framework, initially, the list of registered SMEs was obtained from the Chamber of Commerce Offices in Sindh province that served the population. Owing to time and resource constraints, through computer application technique, 100 SMEs were randomly identified with a background of different economic sectors. The survey questionnaires were mailed to those randomly identified 100 respondent SMEs and repeated follow up phone calls were made in order to solicit more responses. Finally, a research associate was sent in person to the respondent firms who could not mail back, to request the owner/manager to fill in the questionnaire and return it. Resultantly, 96 completely filled-in questionnaires were returned showing the response rate of 96 percent. Though sample size in this study is smaller in number due to study limitations but it is fully representative of all the registered SMEs in the population. Besides, the study of renowned research scholars Scheela, \& Van Dinh (2004), had also used limited firms in their published paper and generalized the results and thus generalizes the study sample of this study.

\begin{tabular}{llll}
\hline JISR-MSSE & Volume 17 & Number 1 & January-June 2019 \\
\hline
\end{tabular}




\section{RESULTS AND DISCUSSIONS}

The results of descriptive statistics in table- 1 show that in all the seven items of financial constraint category the mean scores are nearly four (4) \& above on five-point Likert scale implying that respondent SMEs consider each item as a major obstacle on their way to growth. For the factors related to the internal and external access to finance, the respondents reported these as the most binding constraints to the growth of their ventures. The most severe constraint is found to be the factor "Limited access to external financing hinders my business growth" with a mean value of 4.22 out of 5 and the relatively least severe is said to be the factor "High cost of borrowing negatively affects my business growth" with a mean value of 3.87 out of 5 . This may be because the survey was conducted during the period when the interest rates touched the lowest in the recent history of Pakistan. Given the size of SMEs, it is more preferred to have most of the assets in liquid and marketable items and thus significantly lack in collateralized assets. As a result, firstly it is difficult for them to be eligible for bank loans. Secondly, if they qualify, they get the loan only on higher interest rates. The mean value of this factor is 3.95 out of 5. Applying for a business loan in Pakistan requires cumbersome documentation and lengthy process of loan approval. The loan application process in most of the cases does not run smoothly until a bribe is not offered to the bank personnel involved in the approval of the loan. The descriptive statistics support this notion as its mean value is 3.93 out of 5 . The stringent rules, complicated regulatory framework and subsequent compliance requirements make it virtually impossible for the SMEs in Pakistan to mobilize capital market for its financing needs. There are no specific tailor-made rules for the public listing of SMEs in Pakistan and that puts them at a disadvantageous position with respect to raising public finance for their investment projects. The mean value of this factor is 3.97 out of 5 .

Table 1. Factors of Financial Constraints- Descriptive Statistics

\begin{tabular}{|c|c|c|c|}
\hline Factors of Financial Constraints & $\mathbf{N}$ & Mean & Std. Deviation \\
\hline Limited access to external financing hinders my business growth. & 96 & $\begin{array}{r}4.218 \\
7\end{array}$ & .75677 \\
\hline Lack of Internal financing obstructs my business growth potential. & 96 & $\begin{array}{r}4.072 \\
9\end{array}$ & 63652 \\
\hline $\begin{array}{l}\text { Stringent collateral requirements for loan applications obstructs my } \\
\text { business growth. }\end{array}$ & 96 & $\begin{array}{r}3.947 \\
9\end{array}$ & .77283 \\
\hline Inadequate facilities to access the capital markets hamper business growth. & 96 & $\begin{array}{r}3.968 \\
8\end{array}$ & .77396 \\
\hline $\begin{array}{l}\text { Kickbacks in the process of getting loans from banks significantly hinder } \\
\text { acquiring the loan and my business growth. }\end{array}$ & 96 & $\begin{array}{r}3.937 \\
5\end{array}$ & .72275 \\
\hline The high cost of borrowing negatively affects my business growth. & 96 & $\begin{array}{r}3.864 \\
6\end{array}$ & .74861 \\
\hline $\begin{array}{l}\text { Lengthy and complicated procedures of obtaining loans from banks and } \\
\text { other financial institutions, constrain my business growth. }\end{array}$ & 96 & $\begin{array}{r}4.052 \\
1\end{array}$ & .74509 \\
\hline Valid N (listwise) & 96 & & \\
\hline
\end{tabular}

Source: Authors' calculations 
Table 2. Results of Pearson Correlations

\begin{tabular}{ll|c|c|c|c|c|c|c|c}
\hline & & OP & EF & IF & CR & ACM & PBL & HCB & LP \\
\hline OP & Pearson Correlation & 1 & & & & & & & \\
& Sig. (2-tailed) & & & & & & & & \\
& $\mathrm{N}$ & 96 & & & & & & & \\
\hline EF & Pearson Correlation & $-.470^{* *}$ & 1 & & & & & & \\
& Sig. (2-tailed) & .000 & & & & & & & \\
& $\mathrm{~N}$ & 96 & 96 & & & & & & \\
\hline IF & Pearson Correlation & $-.251^{*}$ & $.229^{*}$ & 1 & & & & & \\
& Sig. (2-tailed) & .041 & .025 & & & & & & \\
& $\mathrm{~N}$ & 96 & 96 & 96 & & & & & \\
\hline CR & Pearson Correlation & $-.326^{*}$ & $.416^{* *}$ & .200 & 1 & & & & \\
& Sig. (2-tailed) & .021 & .000 & .050 & & & & & \\
& $\mathrm{~N}$ & 96 & 96 & 96 & 96 & & & & \\
\hline ACM & Pearson Correlation & $-.278^{*}$ & .156 & .154 & $.208^{*}$ & 1 & & & \\
& Sig. (2-tailed) & .011 & .130 & .133 & .042 & & & & \\
& $\mathrm{~N}$ & 96 & 96 & 96 & 96 & 96 & & & \\
\hline PBL & Pearson Correlation & $-.314^{*}$ & $.218^{*}$ & .079 & $.484^{* *}$ & .185 & 1 & & \\
& Sig. (2-tailed) & .025 & .033 & .446 & .000 & .072 & & & \\
& $\mathrm{~N}$ & 96 & 96 & 96 & 96 & 96 & 96 & & \\
\hline HCB & Pearson Correlation & $-.417^{* *}$ & $.201^{*}$ & .109 & $.261^{*}$ & $.229 *$ & $.471^{* *}$ & 1 & \\
& Sig. (2-tailed) & .000 & .049 & .289 & .010 & .025 & .000 & & \\
& $\mathrm{~N}$ & 96 & 96 & 96 & 96 & 96 & 96 & 96 & \\
\hline LP & Pearson Correlation & $-.296^{* *}$ & $.372^{* *}$ & $.258^{*}$ & $.334^{* *}$ & $.277^{* *}$ & $.397^{* *}$ & $.334^{* *}$ & 1 \\
& Sig. (2-tailed) & .001 & .000 & .011 & .001 & .006 & .000 & .001 & \\
& $\mathrm{~N}$ & 96 & 96 & 96 & 96 & 96 & 96 & 96 & 96 \\
\hline
\end{tabular}

*. Correlation is significant at the 0.05 level (2-tailed).

**. Correlation is significant at the 0.01 level (2-tailed).

Source: Authors' Calculations

The results of Pearson correlations show that all seven factors are negatively correlated with the performance of SMEs validating the descriptive results. Based on the magnitude of correlation coefficient "limited access to external finance" is substantially hampering the SMEs performance as its coefficient is -.47 with .000 (2-tailed) Significance Level. It is followed by the factor "high cost of borrowing" which has a coefficient of -.417 with .000 (2-tailed) significance level. Most importantly the factor "limited access to external finance" is highly correlated with lack of collateralized assets, indicating that stringent collateral requirements of financial institutions severely obstruct the growth of SMEs in Pakistan. This result is in line with the study of Steijvers and Voordeckers (2009). The performance of a firm is multi-dimensional and is influenced by multiple constraint-categories such as marketing, human resource, technological, infrastructural, fiscal, and market constraints. This paper is exclusively focused on the financial constraints and therefore the correlation coefficients are less than .5 and the unexplained variation in correlation is due to the factors not included in this study. Yet, it is inferred that financial constraints explain the substantial degree of variation in the performance of a firm. 


\section{CONCLUSION}

SMEs have been efficiently used as the vehicles for promoting innovation, productivity, and competitiveness of a country's national economy. Across the globe, SMEs have been playing a decisive role in achieving socio-economic objectives such as employment generation, reduction in poverty, equitable distribution of national wealth, fostering innovative culture, and achieving institutional competitiveness (Ndiaye, Razak, Nagayev, \& Ng, 2018). The main objective of this study was to empirically examine the extent to which financial constraints hamper the performance of SMEs in Sindh Province. The results show that SMEs in Pakistan are severely constrained by financing, particularly external equity. Institutional weaknesses and market failures exacerbate the financial constraints of SMEs. Furthermore, the financial ecosystem for SMEs in Pakistan is not friendly and one-size fits all rules and regulations may not suffice the financing needs of SMEs in Pakistan.

It is thus recommended that the government should prioritize SMEs in its policy framework and launch the policies to ease the financial constraints so that SMEs could unleash their full potential. The government especially should develop specialized banks and funds to cater to the financing needs of SMEs in their various stages of the business cycle. Further, Credit Guarantee Schemes (CGS) should also be launched to share the risk of financial institutions for lending to the SMEs. The findings of this study would help managers in understanding the intensity of financial constraints, hampering the performance of their businesses. It will also help the government to develop effective policy interventions for solving the financing issues of SMEs. Finally, it would make a significant contribution toenriching the existing literature on financial constraints to SMEs in Pakistan.

\section{REFERENCES}

Artola, C., \& Genre, V. (2011). Euro Area SMEs under Financial Constraints: Belief or Reality? (No. 3650). CESifo Group Munich.

Banerjee, A. V., \& Duflo, E. (2007). The economic lives of the poor. Journal of economic perspectives, 21(1), 141-168.

Beck, T., \& Demirguc-Kunt, A. (2006). Small and medium-size enterprises: Access to finance as a growth constraint. Journal of Banking \& Finance, 30(11), 2931-2943.

Beck, T., Demirguc-Kunt, A., \& Levine, R. (2005). SMEs, growth, and poverty: cross-country evidence. Journal of economic growth, 10(3), 199-229.

Berger, A. N., \& Udell, G. F. (1998). The economics of small business finance: The roles of private equity and debt markets in the financial growth cycle. Journal of banking \& finance, 22(6-8), 613-673.

Bergthaler, W., Kang, K., Liu, Y., \& Monaghan, D. (2015). Tackling small and medium-sized enterprise problem loans in Europe. International Monetary Fund. Retrieved from https://www.imf.org/external/pubs/ft/sdn/2015/sdn1504.pdf.

Blundell, R., Dearden, L., \& Meghir, C. (1996). The determinants and effects of work-related training in Britain (No. R50). IFS Reports, Institute for Fiscal Studies.

Bond, S., Harhoff, D., \& Van Reenen, J. (1999). Investment, $R \& D$ and financial constraints in Britain and Germany (No. W99/05). London: Institute for Fiscal Studies.

Boschmans, K., \& Pissareva, L. (2017). Fostering Markets for SME Finance: Matching Business and Investor Needs. OECD Publishing.

De la Torre, A., Soledad Martinez Peria, M., \& Schmukler, S. L. (2008). Bank involvement with SMEs: Beyond relationship lending. The World Bank.

106 January-June $2019 \quad$ Volume $17 \quad$ Number 12 JISR-MSSE 
Fort, T. C., Haltiwanger, J., Jarmin, R. S., \& Miranda, J. (2013). How firms respond to business cycles: The role of firm age and firm size. IMF Economic Review, 61(3), 520-559.

Fowowe, B. (2017). Access to finance and firm performance: Evidence from African countries. Review of development finance, 7(1), 6-17. Retrieved from https://www.sciencedirect.com/science/article/pii/S1879933717300106

Frank, M. Z., \& Goyal, V. K. (2003). Testing the pecking order theory of capital structure. $\begin{array}{llll}\text { Journal of financial economics, } & \text { 67(2), }\end{array}$ http://dx.doi.org/10.1016/S0304-405X(02)00252-0

Leaven, L., \& Woodruff, C. (2007). The quality of the legal system, firm ownership, and firm size. Review of Economics and Statistics, 89(4), 601-614.

Levine, R. (2005). Finance and growth: theory and evidence. Handbook of economic growth, 1, 865-934. Elsevier Science: The Netherlands.

Mian, A. (2006). Distance constraints: The limits of foreign lending in poor economies. The Journal of Finance, 61(3), 1465-1505.

Naqvi, S. W. H. (2011). Critical success and failure factors of entrepreneurial organizations: Study of SMEs in Bahawalpur, Pakistan. European Journal of Business and Management, 3(4), 96-99.

Ndiaye, N., Razak, L. A., Nagayev, R., \& Ng, A. (2018). Demystifying small and medium enterprises'(SMEs) performance in emerging and developing economies. Borsa Istanbul Review, 18(4), 269-281.

Rahman, A., Rahman, M. T., \& Belas, J. (2017). Determinants of SME finance: Evidence from three central European countries. Review of economic perspectives, 17(3), 263-285.

Scheela, W., \& Van Dinh, N. (2004). Venture capital in a transition economy: The case of Vietnam. Venture Capital: An International Journal of Entrepreneurial Finance, 6(4), 333-350. DOI: 10.1080/1369106042000258508

SMEDA. (2018). Standards and Certifications: An Overview of SME sector, Market Access, ISO Certifications and Compliance, SME Observer, 8(1),9-14. Accessed at https://smeda.org/index.php?option=com_phocadownload \&view=category\&id=46\&Ite mid=566

St-Pierre, J., \& Bahri, M. (2011). The determinants of risk premium: The case of bank lines of credit granted to SMEs. Journal of Developmental Entrepreneurship, 16(04), 459-476.

Steijvers, T., Voordeckers, W., \& Vanhoof, K. (2010). Collateral, relationship lending and family firms. Small Business Economics, 34(3), 243-259.

Steijvers, T., \& Voordeckers, W. (2009). Collateral and credit rationing: a review of recent empirical studies as a guide for future research. Journal of Economic Surveys, 23(5), 924-946.

Wangmo, C. (2016). Small and Medium Enterprise (SME) Financing Constraints in Developing Countries: A Case Study of Bhutan (Doctoral dissertation, Victoria University). 


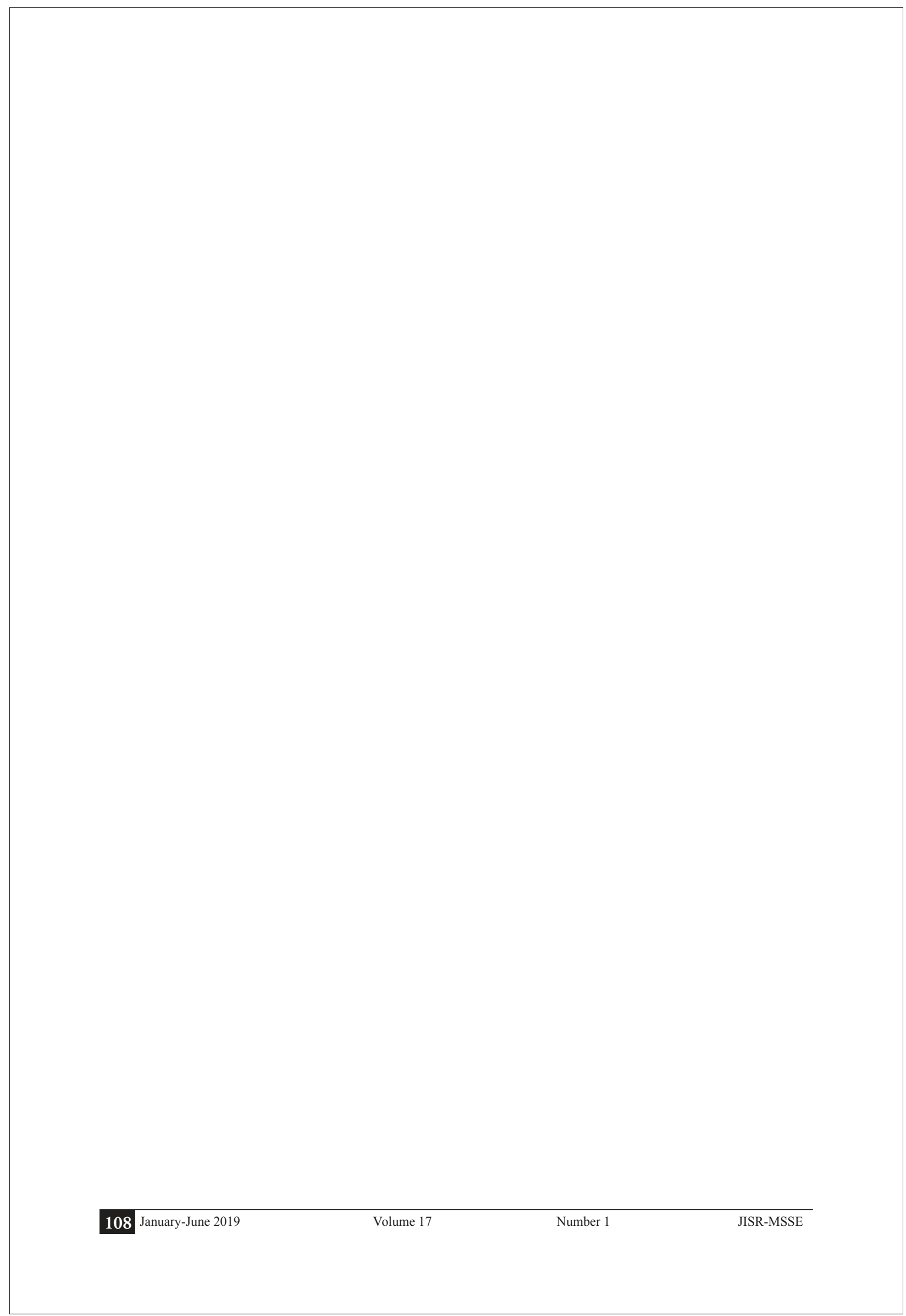

